\title{
ENCANTARIA MARANHENSE DE DOM SEBASTIÃO
}

\author{
Sergio F. Ferretti \\ Universidade Federal do Maranhão, Brasil
}

\begin{abstract}
Resumo: Nas noites de lua, nas areias da Ilha dos Lençóis no Maranhão, Dom Sebastião aparece como touro encantado, e alguns conseguem ver seus tesouros nas dunas. A família de Dom Sebastião, com filhos, nobres de sua corte, cavaleiros, vaqueiros e soldados, é constituída de seres encantados que são recebidos em transe nos rituais de cura e de tambor de mina. O touro de Dom Sebastião constitui uma das vertentes formadoras do festival do bumba-meu-boi e de outras manifestações populares no Maranhão. Através de observações no batizado do boizinho de Dom Sebastião, num ritual de cura, procuramos compreender elementos do sebastianismo maranhense, analisando a presença do sincretismo e do hibridismo como forma de compreensão da religião e da cultura.
\end{abstract}

Palavras-chave: Sincretismo; Hibridismo; Sebastianismo; Pajelança; Mito; Ritual

\section{O Sebastianismo no Maranhão}

A crença num rei encantado que virá salvar o seu povo existe em muitas regiões, podendo ser considerada uma das manifestações do messianismo, ou do mito da espera de um messias ou salvador. O sebastianismo inclui-se entre essas crenças (Hermann: 1998). No Brasil, o sebastianismo foi trazido pelos portugueses, sendo registrado em várias épocas e locais, relacionando-se principalmente ao culto a El Rei Dom Sebastião, que não teria morrido na guerra contra os mouros no Marrocos, mas teria se "encantado"1.

O sebastianismo possui manifestações e peculiaridades em diferentes regiões do Brasil. Uma de suas fontes de difusão foram os jesuítas. Waldemar Valente (1963, p. 61) comenta que em 1656, ao falecer D. João IV, o padre Antônio Vieira pregou na matriz do Maranhão, que D. João estava morto, mas haveria de ressuscitar. Diz que este sermão se perdeu como alguns outros feitos de improviso, mas suas idéias permaneceram, sendo responsável, inclusive, por Vieira ter sido processado pelo Tribunal do Santo Ofício por ter defendido as profecias de Bandarra, ter pregado a volta

\footnotetext{
${ }^{1}$ A respeito da categoria encantado, veja-se Maués (1977, p. 40-41): "Há certo número de pessoas que não morrem e, ao invés disso, se tornam encantados. Dizem que essas pessoas são levadas, muitas vezes ainda crianças, para o encante (local de morada dos encantados), por certos encantados que se agradam delas, como as Mães d'Água. Assim, se uma criança desaparece num rio e seu corpo não for mais encontrado, dir-se-á que aquela criança foi para o encante." Ainda em relação ao termo encantado no tambor de mina e nos salões de curadores do Maranhão, Mundicarmo Ferretti informa: "Refere-se a uma categoria de seres espirituais recebidos em transe mediúnico, que não podem ser observados diretamente ou que se acredita poderem ser vistos, ouvidos ou sentidos em sonho, ou por pessoas dotadas de vidência, mediunidade ou de percepção extra-sensorial." (Ferretti, M, 2000-b, p. 15).
} 
de D. João IV e previsto o advento do Quinto Império. O Padre Antônio Vieira, que viveu durante vários anos no Maranhão, foi condenado pela Inquisição em 1667, mas, em 1675, foi absolvido pelo Papa.

Localizado entre a Região Amazônica e o Nordeste do país, o Estado do Maranhão por muito tempo permaneceu isolado do restante do Brasil e, no período colonial, constituiu por mais de uma vez uma província separada do restante do país. Este isolamento fez com que nele se desenvolvessem características culturais específicas e diferentes de outras áreas. A região recebeu fortes influências ameríndias, européias e africanas.

A presença indígena sempre foi grande dado o contingente populacional ameríndio e, até meados do século XVIII, línguas indígenas eram amplamente utilizadas, mesmo na capital. O europeu chegou, em inícios do século XVII e procurou expandir a lavoura, principalmente da cana de açúcar e do algodão. A catequese dos indígenas se efetuou através diversos empreendimentos missionários católicos. Grande número de escravos foi trazido da África, sobretudo a partir de meados do século XVIII com a criação da Companhia de Comércio do Grão Pará e do Maranhão, organizada pelo Marques de Pombal. Pombal expulsou os jesuítas, fortaleceu as tradições e a língua portuguesa, incrementou a importação de escravos e ampliou a urbanização com a construção de grandes edificações.

No litoral do Maranhão, há regiões com dunas de areias denominadas de lençóis, dentre elas, a Ilha dos Lençóis, no município do Cururupu no litoral Norte, considerada como uma ilha encantada que serve de moradia ou de encantaria a Dom Sebastião e sua corte (Braga, 2001; Pereira: 2000; Andrade: 2002). As areias dos Lençóis lembrariam a região da África em que o rei teria desaparecido. No vizinho Estado do Pará, há também regiões conhecidas como morada ou encantaria de Dom Sebastião (Maués, 1977; Vergolino-Henry, 2004; Luca, 2010). Existe na Ilha dos Lençóis uma comunidade de albinos que são denominados de filhos do Rei Sebastião. O culto ao Rei Sebastião no Maranhão e no Pará, conforme Taissa Luca (2010, p. 112):

\footnotetext{
"esvaziou a conotação messiânica da crença no "Encoberto". Nenhum mineiro espera o retorno do rei, simplesmente porque nenhum culto afro-brasileiro possui característica salvacionista. Nessa religião de integração, o sagrado imanente se faz presente cotidianamente em meio a experiência extática. $\mathrm{O}$ retorno do rei acontece a cada festa pública, sempre que um filho-de-santo recebe esta entidade."
}

A presença do sebastianismo no Maranhão e no Pará pode ser estudada como um caso de hibridismo cultural ou de sincretismo religioso como comentamos adiante, 
englobando elementos culturais portugueses com tradições culturais e religiosas de origens ameríndias e afro-brasileiras. Denominando as crenças sebásticas maranhenses de "sincretismo afro-caboclo" e considerando-as fruto do hibrismo, Jacqueline Hermann (2008, p. 40) afirma:

\begin{abstract}
"Minha pesquisa sobre os sebastianismos luso-brasileiros encontrou no caso maranhense, diversas inovações e especificidades que, de forma clara, agrega elementos da religiosidade africana e ameríndia, conformando, talvez, a versão mais genuinamente "brasileira" da crença sebastianista, na medida em que parece fundir e reelaborar aspectos importantes das três matrizes "originais" de nossa formação cultural."
\end{abstract}

"Rei, Rei, Dom Sebastião, quem desencantar Lençóis bota abaixo o Maranhão" é o refrão de uma conhecida toada repetida nos cânticos dos terreiros em homenagem a Dom Sebastião, prevendo uma catástrofe com o desaparecimento do reino deste mundo que seria transformado no reino do outro mundo, como ocorre em muitos mitos de inversão. O mito da vinda de Dom Sebastião e os ritos relacionados com sua presença atual em São Luís constituem exemplo interessante do imaginário de mitos de origem "que procuram forjar uma identidade própria no tempo e no espaço sagrado" (BAPTISTA, 2010). Vamos apresentar informações sobre esse mito a partir de da descrição de um ritual religioso da cultura popular maranhense.

\title{
2. Religiões Afro-maranhenses
}

Na cultura popular afro-maranhense, que se difunde também pela Amazônia, há duas manifestações religiosas específicas, o Tambor de Mina e a Cura ou Pajelança, além da Umbanda e do Candomblé que foram trazidos de outras regiões do país.

O Tambor de Mina é mais encontrado na capital e se caracteriza pelo predomínio de entidades africanas, voduns e orixás e a inclusão de caboclos. Estes, na maioria, não são de origem ameríndia. Muitos são nobres europeus que se encantaram na mina ou são entidades brasileiras. O nome Tambor de Mina deriva da importância do tambor entre os instrumentos musicais e do forte de São Jorge da Mina, na atual República do Gana, por onde foram importados muitos escravos africanos.

O Tambor de Mina também é conhecido como Linha da Água Salgada, significando que suas entidades vieram do outro lado do oceano. Possui características semelhantes às demais religiões afro-brasileiras como o Candomblé da Bahia, mas tem especificidades locais que o diferenciam. Como as demais religiões afro-brasileiras, o Tambor de Mina conserva elementos e características africanas, sendo, porém, uma religião afrobrasileira que se distingue das religiões africanas originais. O Tambor de Mina é 
participado predominantemente por mulheres Nas casas mais antigas e tradicionais, a liderança é sempre feminina e, em algumas, só mulheres podem receber e dançar com as entidades. Atualmente há muitos terreiros dirigidos e com a participação de homens, embora com predomínio do número de mulheres.

A outra vertente ou manifestação religiosa difundida, sobretudo, nas regiões da Baixada e do Litoral Maranhense, é a Cura ou Pajelança² ${ }^{2}$ denominada Linha de Água Doce, significando que as entidades cultuadas são brasileiras em sua maioria. A pajelança recebe influência das religiões ameríndias, mas apresenta elementos africanos e europeus. Encontra-se também na região Amazônica e tem semelhanças com o culto da Jurema do Nordeste (ASSUNÇÃO, 1999).

Há muitas diferenças entre o Tambor de Mina e a Pajelança. Na Mina, várias pessoas entram em transe ao mesmo tampo e dançam em roda. Diversas pessoas recebem sua entidade e permanecem em transe com ela durante quase todo ritual. Na Cura, o transe costuma ocorrer em uma pessoa que recebe sucessivamente diferentes entidades. Oferecem a ela duas ou três saudações e a entidade se retira, sendo substituída por outra. Ao longo da noite, o pajé ou a pajoa pode receber cerca de uma centena de entidades que ficam pouco tempo. O pajé segura um maracá, um penacho de arara, amarrando os braços e a cintura com fitas. As entidades se agrupam em linhas e são considerados como encantados em pássaros, peixes, répteis e outros animais, ou em príncipes, princesas e caboclos. Os instrumentos musicais da mina são dois ou três tambores acompanhados de cabaças. Na cura, usam-se principalmente pandeiros e palmas, podendo também haver acompanhamento com tambores.

Em São Luís, muitos terreiros, paralelamente aos rituais de mina, organizam uma ou duas vezes ao ano um brinquedo de cura para saudar as entidades da pajelança. Algumas vezes, na pajelança, uma entidade realiza rituais de cura para clientes, extraindo magicamente um objeto do seu corpo e dando conselhos ou ensinando remédios. No interior, este ritual é mais frequente.

As casas de Mina mais antigas que se continuam no Maranhão foram fundadas por africanos em meados do século XIX, sendo uma de origem daomeana ou jeje, a Casa das Minas e outra de origem yorubana ou nagô, a Casa de Nagô. Na casa Jeje, os voduns se agrupam em famílias e este modelo se difundiu no Tambor de Mina, onde as demais entidades cultuadas também costumam se agrupar em famílias. As entidades

\footnotetext{
${ }^{2} \mathrm{O}$ ritual de cura ou pajelança é também chamado de brinquedo ou brincadeira de cura, expressão usada desde pelo menos o final do séc. XIX para encobrir práticas religiosas sob o manto de diversões profanas (Ferretti, M. 2000-a; Pacheco, G. 2004)
} 
sobrenaturais no Maranhão e na Amazônia são também denominadas de encantados, pois vivem num mundo ou reino especial, a encantaria.

Uma das famílias de entidades mais importantes e conhecidas no Tambor de Mina é a família do Rei da Turquia. Segundo Mundicarmo Ferretti (2000, p.129):

"O Rei da Turquia surgiu como entidade espiritual no Tambor de Mina em São Luís, na casa do pai-de-santo conhecido por Manuel Teu Santo (que acredita-se ter nascido na África e que teria falecido no final do século XIX). Surgiu numa casa que parece ter sido mais ligada ao Terreiro do Egito [...] Seu Turquia foi recebido ali por Anastácia Lúcia dos Santos, filha de negros de uma fazenda de algodão de Codó (MA) e que viera, há pouco tempo, para a capital. Esta por volta de 1889 abriu em São Luís o terreiro que foi o "berço" da linhagem dos turcos no Tambor de Mina e que ficou conhecido por Terreiro da Turquia."

Mundicarmo Ferretti (1989) publicou diversos trabalhos sobre a família da Turquia no Tambor de Mina, tendo constatado que a fonte de informação na gênese desta família foi o romance "A História do Imperador Carlos Magno e dos Doze Pares de França". Este livro foi muito difundido no Brasil no século XIX e teve larga divulgação na literatura de cordel. As lutas de Turcos e Mouros, as Cheganças e Marujadas também foram manifestações culturais importantes no Nordeste e divulgaram informações sobre lutas entre mouros e cristãos. Mundicarmo Ferretti (1989) constatou que alguns personagens das Histórias de Carlos Magno se encontram na família do Rei da Turquia no Tambor de Mina, entre os quais, Ferrabrás (O Rei da Turquia), Guerreiro de Alexandria, Princesa Dora, Princesa Flora, Floripes. A maioria dos filhos desta família possui nome indígena ou de outras origens $^{3}$.

Vemos, assim, que o imaginário religioso afro-maranhense é influenciado por tradições procedentes de várias regiões, inclusive da Europa. Outra família importante de encantados presente no Tambor de Mina e na Pajelança é a família de Dom Sebastião. Nos últimos anos, a mitologia das religiões afro-brasileiras e ameríndias no Maranhão tem sido relativamente mais estudada, embora ainda haja muito a ser conhecido.

Na religiosidade popular maranhense, a festa de São Sebastião, no dia 20 de Janeiro, é uma das mais importantes, sendo comemorada em quase todos os terreiros. Muitos deles oferecem um banquete aos cachorros para São Lázaro (Ferretti, S. 2001). Nesta festa, são comemorados, sobretudo os voduns da família de Odam ou de Acossi- Sakpatá entre os jeje

\footnotetext{
3 Mundicarmo Ferretti (200o, p. 318 - 319) relaciona diversas entidades desta família entre as quais Aquilital, Burlante, Caboclo Nobre, Menino Dalera, Guajajara, Iracema, Ita, Jaguarema, Japetequara, Jarina, Jariodama, Juracema, Jureminha, Maresia, Mariana, Paraense, Itabajara, Tapindaré, Ubirajara.
} 
e da família de Légo Shapanã entre os nagô, também conhecido como Sebastião na Casa de Nagô e em outros terreiros. A tradição do culto a Dom Sebastião, relacionada com o mito do sebastianismo, se constitui uma das fontes do imaginário religioso e da cultura popular local. O culto à família de Dom Sebastião está presente no Tambor de Mina e nos rituais de Cura ou Pajelança, englobando entidades consideradas nobres ou gentis ${ }^{4}$.

José Reginaldo Prandi e Patrícia Souza apresentam muitas informações sobre a família de Dom Sebastião, também conhecida como Família do Lençol, coletadas no terreiro de Tambor de Mina em São Paulo, do falecido pai-de-santo Francelino de Xapanã. Prandi e Souza (2001, p. 220-234) informam que o chefe da família, Dom Sebastião se encantou no Maranhão na Praia dos Lençóis, é homenageado no dia de São Sebastião junto com os voduns Xapanã e Acossi Sakpatá e sua cor predominante é o vermelho. Informam também que Dom Sebastião passa de sete em sete anos na casa de Francelino e vem muito velho, mas demonstrando grande alegria. Segundo Prandi e Souza, trata-se de uma família de reis e fidalgos, denominados gentis 5

Em alguns terreiros, o Rei Sebastião se incorpora nos devotos na forma de um touro, chamado de boi Turino e a pessoa que o recebe dança ajoelhada, com as mãos ciscando o chão e bufando como um touro. Geralmente este transe dura pouco tempo, como vimos em São Luís, no terreiro de Margarida Motta e na cura de dona Raimundinha, que comentaremos adiante. No terreiro de Santa Luzia, de dona Benedita, no Bairro da Aurora, assistimos a uma visita do grupo de Bumba-meu-boi Boizinho Incantado, que possui muitas músicas relacionadas a Dom Sebastião. Uma das entidades da família de Dom Sebastião nesta casa é a princesa Jandira. Em geral, os participantes do Tambor de Mina e da Pajelança fazem certo mistério e não costumam falar sobre suas entidades, sobretudo as relacionadas com a família do Rei Sebastião.

Mundicarmo Ferretti (2004, p. 204) constata que no processo contra a pajé Amélia Rosa, ocorrido em São Luís no século XIX, entre 1877-78, havia pessoas ligadas a seu grupo de culto que recebiam São Lázaro e Rei Sebastião, demonstrando a presença desta tradição em São Luís pelo menos desde a década de 1870. Rei Sebastião também é cultuado no vizinho Estado do Pará e vem em diversos devotos da Mina (Maués e Vilacorta, (2008),

\footnotetext{
${ }^{4}$ Em São Luís, este culto inclui entre outras entidades a princesa Iná, a princesa Jandira, Sebastiãozinho, Dom Sebastião, seus vaqueiros e outras.

${ }^{5}$ Prandi e Souza incluem entre os reis e rainhas desta família, além d o Rei Sebastião, Dom Luiz, rei de França, Dom Manoel, Dom José Floriano, Dom João Rei das Minas, Dom João Soeira, Dom Henrique, Dom Carlos, Rainha Bárbara Soeira, Rainha Dina, Rainha Rosa, Rainha Madalena. Entre príncipes e princesas: Príncipe Orias, Príncipe de Oliveira, Príncipe Alteredo, Tói Zezinho, Boço Lauro, Tóia Jarina, Princesa Flora, Princesa Luzia, Princesa Oruana, Princesa Clara, Dona Maria Antônio, Moça Fina. Entre os nobres inclui: Duque Marques de Pombal, Ricardino Rei do Mar, Barão de Guaré, Barão de Anapoli.
} 
Vergolino-Henry (2004).

\section{Religião e festas da cultura popular no Maranhão}

Muitos terreiros de Tambor de Mina e de Umbanda do Maranhão costumam realizar festas da cultura popular oferecidas em homenagem a encantados que as apreciam e solicitam. Assim é comum a realização nos terreiros da Festa do Divino Espírito Santo, do Tambor de Crioula, do Bumba-meu-boi e outras. Geralmente, no dia em que determinada entidade é cultuada, a ela é oferecida uma ou várias destas festas. Os membros dos grupos de afro-religiosos pertencem à mesma classe dos participantes das manifestações da cultura popular. Assim, religião e cultura popular encontram-se muito próximas, uma contribuindo e apoiando o desenvolvimento da outra.

No Maranhão, a Festa do Divino é realizada principalmente nos grupos de culto afrobrasileiros de Tambor de Mina. Quase todos os terreiros de Mina organizam uma vez ao ano esta festa oferecida a uma entidade devota do Divino que solicita a festa em sua homenagem. Como é muito dispendiosa, geralmente é organizada na época da principal festa do terreiro. Alguns terreiros a realizam no período de Pentecostes da Igreja Católica. Outros a organizam ao longo do ano, sendo oferecida à entidade na data de determinado santo do calendário católico como Senhora Sant’Ana, São Luís, São Raimundo, N. Sra. da Conceição, etc. Nos terreiros, geralmente a Festa do Divino dura de uma a duas semanas e se continua com a realização de festas religiosas com toques para as entidades cultuadas.

Um dos elementos característicos dessa Festa no Maranhão é a presença de mulheres que tocam caixas ou caixeiras, que entoam cânticos conhecidos de cor ou feitos de improviso durante o ritual. As caixeiras se apresentam em número variado e são quase que exclusivamente mulheres. São lideradas pela caixeira régia e pela caixeira mor, que conhecem todos os cânticos e elementos rituais. Em alguns momentos, elas executam uma dança, acompanhadas por bandeireiras, meninas que seguram bandeiras e dançam diante do império ou do mastro. Acompanham o império durante os deslocamentos, visitas ou procissões e tocam por devoção, recebendo pequenas ajudas para deslocamentos. Devem ser cuidadosas para que não ocorram erros durante o ritual que pode significa um mau presságio.

Nas Festas do Divino Espírito Santo, comemoradas na cultura popular maranhense, a nosso ver, podem ser encontradas algumas conotações messiânicas e milenaristas. Trata-se de uma festa que apresenta elementos de fartura, de luxo, de um império que mitiga a pobreza e a fome. Os nobres devem distribuir alimentos a todos e dar as sobras aos mais necessitados. Arrecadam-se recursos entre os amigos e faz-se um grande 
esforço para que a festa seja cada vez mais bonita e abundante. Não deve ocorrer nenhum erro durante os rituais, o que costuma ser visto como presságio de coisa ruim, ou da morte de pessoa importante entre os organizadores. A bandeira do mastro não pode ficar em posição errada; o mastro quando carregado e símbolos como a pomba, a coroa, o cetro também não podem cair. As mulheres que tocam as caixas devem cuidar para que todas as coisas sejam feitas sem erro, a fim de que não ocorram coisas ruins.

Outra manifestação da cultura popular maranhense é o Tambor de Crioula. Trata-se de uma dança folclórica de divertimento e uma forma de pagamento de promessa a São Benedito, a outros santos como aos Pretos Velhos e a outras entidades caboclas ou africanas cultuadas. Algumas casas de Mina possuem grupos de Tambor de Crioula e muitos grupos se apresentam regularmente em terreiros para agradar entidades que apreciam esta manifestação. Em 2006, o Tambor de Crioula foi incluído no registro do Patrimônio Imaterial Brasileiro pelo Instituto do Patrimônio Histórico e Artístico Nacional. Em São Luís, existem atualmente cerca de 80 grupos de Tambor de Crioula que, ao longo do ano, fazem apresentações folclóricas para turistas e realizam festas como forma de pagamento de promessa, muitas vezes em terreiro de Tambor de Mina. A dança é feita em roda pelas mulheres que dão entre si uma umbigada enquanto os homens tocam tambores e entoam cânticos conhecidos ou de improvisos.

No folclore maranhense, o bumba-meu-boi constitui manifestação popular que atrai grande número de participantes. O boi no Maranhão é brincado, sobretudo no mês de junho em homenagem a São João, e o ciclo das festas se estende de abril a outubro. Há mais de trezentos grupos de bumba-meu-boi organizados em São Lues, reunindo uma centena ou mais participantes. Os bois se subdividem em sotaques que se relacionam com os instrumentos, o vestuário e tipos de danças. Os sotaques mais conhecidos são os de matraca, de zabumba e de orquestra.

Muitos grupos de boi se apresentam em terreiros de Umbanda e de Tambor de Mina. Diversos terreiros oferecem uma festa com bumba-meu-boi para entidades que apreciam esta manifestação e alguns possuem seu próprio boi. É comum nos terreiros haver festa para o batizado e para a morte do boi oferecido à entidade, que são denominados de boi de encantado. Diversos bois são organizados nos terreiros em homenagem a Dom Sebastião, como o Boizinho Incantado ${ }^{6}$.

Assim no Maranhão a estória de Dom Sebastião está relacionada, com os rituais e festas dos grupos de culto afro-religiosos de tambor de mina e de cura ou pajelança bem como

${ }^{6}$ O Boisinho Incantado é considerado um boi alternativo, com múltiplos estilos ou sotaques, utilizando pandeirões, zabumba, instrumentos de corda, guitarra elétrica, gaita, etc. Possui músicas gravadas, inclusive uma que fala de Dom Sebastião no terreiro de dona Benedita. 
com festas da cultura popular em grupos de bumba-meu-boi. As festas de boi nos terreiros de Mina costumam ser oferecidas a entidades diversas7 ${ }^{7} \mathrm{Em}$ algumas casas, a festa do boi se continua com toques nos terreiros.

\section{Lendas do Sebastianismo no Maranhão}

A Ilha dos Lençóis no Município de Cururupu, no litoral norte do Maranhão, é considerada como local em que o Rei Dom Sebastião encontra-se encantado. Pessoas que a visitam, sobretudo os que possuem dons mediúnicos, umbandistas, mineiros curadores ou pajés, contam terem visto o rei encantado num touro e muitos dizem ter tido visão dos tesouros de Dom Sebastião. Dizem que Dom Sebastião costuma aparecer principalmente em junho, durante as festas do bumba-meu-boi, em agosto, época do aniversário da batalha de Alcácer-Quibir, ou em janeiro, na festa de São Sebastião. Dizem também que, atualmente, o Rei já não está mais aparecendo porque "a praia dos Lençóis está sendo muito visitada e já possui muito morador" (PEREIRA, 2000, p. 94).

Esta não vinda reflete o pessimismo, ou idéias de desastre, do imaginário popular, de que, no passado, os tempos eram melhores e o presente degrada ou polui o ambiente. Essa crença, difundida em muitos mitos, parece estar de acordo com previsões de ambientalistas, segundo as quais, o desmatamento e a destruição dos manguezais têm provocando alterações no planeta. Os antigos dizem que era comum acharem jóias na praia $^{8}$ e por isso os visitantes são proibidos de levar qualquer coisa da Ilha. Os pescadores acreditam que, se alguém sair levando conchas e lembranças, a embarcação não pode seguir viagem, pois tudo lá pertence ao tesouro do rei. Se insistirem, a embarcação pode afundar.

No Maranhão, circulam várias narrativas relacionadas a este mito como a do Navio encantado de Dom Sebastião, que é visto pelos viajantes no local conhecido como Boqueirão, no Golfão Maranhense. Há também a lenda do Navio encantado de Dom João, que era visto pelos frequentadores do antigo Terreiro do Egito no local próximo ao porto do Itaqui em São Luís. Há o mito da Princesa Iná, filha do Rei Sebastião, que ficou revoltada quando seu palácio, no fundo do mar, foi perturbado pela construção do Porto do Itaqui (LIMA NETO, 2005).

\footnotetext{
7 Como Seu Légua, Seu Preto Velho, Seu Corre Beirada, Seu Beberrão, Seu Surrupirinha, Seu Tombassé, Seu Zezinho, Joãozinho de Légua, Luizinho, filho de Dom Luís, Rei Sebastião, Seu Lealdino - vaqueiro de Dom Sebastião e outros.

${ }^{8}$ Ver Ferretti, M. 2000-b, p. 77 e Pereira, 2000.
} 
Durante a construção do porto do Itaqui ${ }^{9}$, em São Luís, aconteceram diversos acidentes graves e alguns escafandristas morreram. Pais-de-santo, liderados pelos falecidos Jorge de Itacy e Sebastião do Coroado, divulgaram a notícia que o porto era o local da encantaria da princesa Ina, ou Iná, filha do rei Dom Sebastião e que a princesa estava revoltada, pois seu palácio, no fundo do mar, fora perturbado pelas obras e por isso escafandristas estavam morrendo. Para acalmar a ira da princesa, aqueles religiosos prometeram oferecer sacrifícios e organizar uma grande festa, reunindo representantes de diversos terreiros na praia Boqueirão, próximo ao local. Foi o que ocorreu em 1970, com ampla divulgação pela mídia e apoio de autoridades municipais, como tivemos oportunidade de assistir na época. Depois disso não ocorreram mais acidentes na construção do porto. Alguns pais-de-santo, entretanto, dizem que, de tempos em tempos, as oferendas precisam ser renovadas para evitar futuros problemas no porto.

Estes incidentes e o mito relacionado à princesa Iná, lembram a "lenda do emparedado”, ilustrada na Albânia por Ismail Kadaré (1999), segundo a qual uma obra construída durante o dia era demolida à noite, até que um ancião previu que, para a obra ser terminada, seres superiores exigiam um sacrifício humano que conseguisse fazer as pazes do encontro da terra com as águas. Mitos e lendas, como sabemos, possuem variantes similares em regiões longínquas do planeta.

O escritor maranhense Jomar Moraes (1980, p. 20), considera que: "A lenda de D. Sebastião é, sem dúvida, a que mais entranhadamente penetrou na alma maranhense, inspirando cantadores de boi, compositores populares, poetas, romancistas e pintores”. Moraes exemplifica a afirmação citando vários trabalhos de escritores, poetas, pintores, bem como cantigas de boi e de terreiros sobre o tema.

\section{História de Dona Raimundinha}

Vamos exemplificar, neste ensaio, sobre aspectos do sebastianismo no Maranhão, narrando elementos da história de uma curadeira. Dona Raimunda Nonata Silva Viegas, filha de um lavrador, nascida na cidade de Codó, importante núcleo de religiões afro-maranhenses (FERRETTI, M., 2001), recebeu o nome de Raimunda, por promessa de sua mãe a São Raimundo Nonato. Sua avó materna era parteira e curadeira. Raimundinha ajudava a mãe, que também era curadeira. O pai se mudava muito e ela

\footnotetext{
9 O complexo do porto do Itaqui é local de exportação do minério extraído da Serra dos Carajás, que é trazido por ferrovia construída pela Vale do Rio Doce. Pelo porto do Itaqui, são também exportadas barras de alumínio laminadas pela Alcoa. Sua construção, em inícios da década de 1970, foi de grande importância estratégica na economia do Norte do país. O porto foi construído nas proximidades de um canal natural muito profundo (o Boqueirão), que permite $o$ aportamento de navios de grande calado, apesar das marés maranhenses, as mais altas do país, que sobem e descem numa oscilação com cerca de oito metros de profundidade.
} 
viveu em vários povoados e municípios. Aos seis anos, quando a avó morreu, ela começou a ter problemas de mediunidade, que considera como herdeira do ventre da mãe $e^{10}$.

Ela nos informou que veio para São Luís, "trazida por um encantado". Era mocinha e veio com uma colega. Levaram-na à casa do curador Zé Cupertino, um dos fundadores da Umbanda no Maranhão, onde foi encruzada, ou preparada como pajoa, em 1957. Morou hospedada, depois comprou uma casa à prestação. Queria ser artista, gostava de drama, de pastores, aprendeu e fez vários cursos, inclusive curso médio de enfermagem e trabalhou num hospital e no comércio, vendendo coisas e ganhando dinheiro. Vendia ouro e outras coisas, como sofá e bicicleta numa casa de comércio que registrou. Também teve uma loja de produtos de Umbanda. Foi casada por quatro anos e passou a se chamar Raimunda Viegas ${ }^{11}$.

Desde o tempo em que dançava no terreiro de Zé Cupertino, frequentava as festas grandes na casa dele e, com sua autorização, fazia também trabalhos religiosos em casa. Fazia gira aos domingos e, na semana, seção esotérica, que trabalha com chave e disse que gosta muito do esoterismo ${ }^{12}$. Após o falecimento de Zé Cupertino, foi iniciada no candomblé por pai Euclides, na Casa Fanti Ashanti, e lá cumpriu as obrigações da feitoria.

Dona Raimundinha atende clientes utilizando diversos tipos de terapia, sobretudo, preparando banhos, garrafadas e aplicando massagens ${ }^{13}$. Em maio, reza ladainha para

\footnotetext{
${ }^{10}$ Informou que sua mãe, falecida há mais de vinte anos, recebia bicho d’água (Mãe D’Água), foi preparada no interior de Codó pelo curador Zé Colodino e por Dona Nazá. Ela trabalhava com várias ervas como angaçu (contra feitiços), cabeça de negro, jalapa, pinhão branco e muitas outras.

${ }^{11}$ Dona Raimundinha conta que uma vez decidiu ir para o Rio de navio, mas o encantado a pegou e a trouxe de volta. Perdeu a passagem e não foi. Depois ganhou um terreno em Brasília, numa promoção, quando estavam construindo a cidade. Foi vender o terreno e de lá foi ao Rio, onde morou e trabalhou por dois anos. Estava no Rio quando passou mal, sendo internada no Hospital Miguel Couto. Ela teve uma hemorragia, fizeram curetagem e disseram que ela tinha um cisto no ovário e teria que ser operada. Na noite de São João, ficou olhando numa janela do hospital e fez promessa para o santo de que se ficasse boa voltaria ao Maranhão e iria brincar boi. Pediu saúde a São João, pois queria voltar e viver bem com a mãe e os filhos adotivos. Desde criança adotou muitos filhos, pois nunca teve nenhum. O curador Zé Cupertino afirmou a seus familiares que ela voltaria boa. Poucos dias depois, ela voltou e ficou curada daquele problema. Passou então a dançar como brincante, por promessa, num grupo de bumba-meuboi, nos anos de 1960.

${ }_{12}$ Participou do Círculo Esotérico Comunhão do Pensamento e foi Rosa Cruz, trabalha com cristais, faz massagens, recebe audição de mensagens. Também fez, por muito tempo, toques para Ogum, Iemanjá, Xangô e organizava todos os anos em junho uma Festa do Divino no salão em sua casa.

${ }_{13}$ Num dos dias em que a procuramos, encontramos pessoa conhecida que disse ter conseguido grande melhora de um AVC com massagens e outros tratamentos que ela realizou.
} 
N. Sra. da Conceição. Em junho, fazia a festa do Divino, dançava no boi e fazia a cura em novembro. Depois passou a fazer apenas a cura. Seu toque de cura é sempre perto de seu aniversário, no dia 29 de novembro, ou no fim de semana mais próximo.

Acura de Dona Raimundinha se inicia com uma ladainha, como ocorre nas festas populares e que normalmente são cantadas em latim, seguida de cânticos em louvor ao santo comemorado. Depois faz a abertura da cura cantando paras entidades que são mestres, nobres, caboclos e encantados. O ritual é demorado, costuma começar pelas vinte e três horas e o curador ou pajé dança até o amanhecer, pois "é preciso chamar todas as linhas”. Dona Raimundinha nos informou que trouxe a promessa do boi para o ritual de cura, fazendo a junção de um ritual religioso com elementos da cultura popular, como é comum na religiosidade afro-maranhense (FERRETTI, S, 2004-b). No dia seguinte, pela manhã, o boi sai para visitar amigos e padrinhos antigos no bairro. Na volta se canta até a morte do boi no fim da tarde.

Para o ritual da cura, ela diz que prepara uns 10 a 15 tauaris ${ }^{14}$. Durante a cura, Dona Raimundinha bebe chá, café e refrigerante, mas não toma bebidas alcoólicas. De tempos em tempos, pede à ajudante que derrame bebida no seu pé e afirma que os encantados "bebem cachaça pelo pé dela". Na cura, cantam para vários nobres como Dona Ana da Corte, Príncipe Navalheiro, Dom João Guerreiro e outros.

O nome do boi é Estrela Maior, em homenagem à estrela Dalva. O vaqueiro é João José Lealdino, vaqueiro do Rei Sebastião. Segundo Dona Raimundinha, ele mora nos morros de areia e nos igarapés da Ilha dos Lençóis (Pereira, 2000). O boi Turino é o Rei Sebastião. Dona Raimundinha conta que já viu o palácio dele. É um palácio pequeno, azul e branco com uma escadaria, parecido com um coreto. Na frente, há uma bandeira das cruzadas, com uma cruz vermelha.

Segundo MORAES (1980), no Maranhão, Dom Sebastião foi encantado num touro com uma estrela de ouro na testa. Se alguém conseguir ferrar a estrela de ouro com a vara de ferrão ${ }^{15}$, os Lençóis vão desaparecer e vem abaixo o Maranhão, como diz o refrão de uma das toadas mais conhecidas. Dona Raimundinha conta que Dom Sebastião é seguido por vaqueiros, príncipes e princesas. Princesa Iná é filha dele, mora no Porto do Itaqui e faz corrente com as águas dos Lençóis. Dom Manuel mora no Boqueirão, Urubarana é nobre, encantada numa sereia. Princesa Flora é da Ponta da Areia. O boi

${ }^{14}$ São cigarros, segundo ela, feitos hoje com papel de caderno, pois não existe mais papel Abade próprio para fazer cigarro. O tauari leva várias ervas como alfazema, noz moscada, pichuí, alecrim, folha de fumo e outras.

15 Vara de ferrão é um instrumento de madeira com cerca de dois metros, enfeitado com papel de seda colorido e recortado. Costuma ser usado em certos grupos de bumba-meu-boi de São Luís. 
Turino é do Maitá, que é nome de uma pedra no mar. O vaqueiro era um guerreiro fiel de Dom Sebastião que sempre andava ao lado do rei. Na encantaria, ele virou vaqueiro, mora nos morros de areia e está sempre ao lado de Dom Sebastião. Dona Raimundinha disse que há outros vaqueiros como Zé Raimundo e que o vaqueiro Lealdino ela só conhece na cura de sua casa, nunca o tendo visto vir em outra pessoa. Diz que Dom Sebastião é um senhor idoso que, em vida, na terra, gostava de corridas de porcos e de touradas, por isso encantou- se num touro, chamado de Boi Turino. É interessante essa espécie de cartografia da moradia dos encantados que Dona Raimundinha descreve, indicando que as entidades estão encantadas em animais como o touro, sereia e em vários acidentes do litoral como ilhas, praias, porto e pedras da região.

Vemos, na história de vida de Dona Raimundinha, sua passagem por religiões populares e a realização de diversas práticas alternativas de cura e estilos de vida. Suas crenças e visões refletem a presença do sincretismo e do hibridismo cultural nos mitos e nos rituais que possuem elementos de origens variadas. Constatamos que a história de vida, as crenças e as práticas religiosas de Dona Raimundinha constituem exemplo que pode ser encontrado em outros curadores, com entre outras pessoas da região, em que podemos identificar a confluência do sincretismo religioso e do hibridismo cultural.

\section{O Batizado do Boizinho de Dom Sebastião na Cura}

Vamos descrever um ritual de cura ou brinquedo de cura, em homenagem ao boizinho de Dom Sebastião, que assistimos algumas vezes na casa de Dona Raimundinha, semelhantes aos realizados em outros terreiros do Maranhão.

Assistimos à cura de dona Raimundinha, tiramos fotos, fizemos gravação e filmagem de vídeo, com a colaboração de estudantes. Realizamos entrevistas com Dona Raimundinha e fomos lhe mostrar fotos e vídeo ${ }^{16}$. Ela afirma que costuma passar a noite anterior preparando comidas e a noite seguinte na cura ${ }^{17}$. Quando chegamos mais cedo, vamos aos fundos da casa esperar a abertura, quando ela chama todos para rezarem a ladainha.

\footnotetext{
16 Numa entrevista, ela pediu cópia do vídeo que fizemos e nos convidou para padrinho da próxima festa do boizinho, pois soube que durante aquela cura o vaqueiro me havia entregado a vara de ferrão para segurar.

17 Dona Raimundinha nos recebe sempre muito bem, dizendo que adora pesquisadores. Conta várias coisas sobre a cura e afirma que recebe diversas "ordens" de mestres - nobres, duques, reis, príncipes, soldados, depois os bichos de todas as categorias, peixes, aves - e que a cura dura a noite toda, pois tem que atender aos 4 elementos: terra, água, ar e fogo. Disse que o curador é conhecido como pajé, ou doutor do mato, e usa vários nomes populares relacionados com doenças e objetos, que todos têm um tipo de mediunidade, cantam cantigas comuns em todas as curas e algumas específicas de cada casa.
} 
Os convidados são chamados para o jantar ou se servirem de bolo e refrigerantes. No dia seguinte, ela serve uma feijoada e enfeita um galho de árvore, denominado de mourão, junto ao qual, pelas 17 horas, ocorre o ritual da morte do boi. Atualmente, a festa está sendo reduzida, devido a problemas de idade e de saúde da organizadora.

No centro da casa, junto à parede, é colocada uma pequena mesa de cura com imagens de santos, charutos de tauari e vários tipos de bebida. Durante o ritual, o padrinho do boi, de tempos em tempos, serve aos tocadores e aos presentes, bebida num garrafão de vinho. Por volta das 23 horas, começa a ladainha e, antes das 23h30, Dona Raimundinha abre a mesa da cura.

Anotamos partes dos cânticos, alguns bonitos e poéticos. A curadora faz gestos, representando a entidade para a qual se canta. Costuma estar muito animada o tempo todo, incentivando os presentes no salão, bebendo, fumando muito, às vezes jogando cachaça nos pés descalços. No início, costuma haver poucos tocadores, de terreiros amigos, depois chegam outros. Geralmente usam camisa com dizeres: "Lembrança da festa do boizinho - Estrela Maior”. Os tocadores acompanham a cura tocando pandeiros. Amigos, clientes, pais e mães-de-santo e participantes de outros terreiros costumam assistir à festa todos os anos.

Após a abertura, cantam para encantados que são princesas, nobres e para bichos, como borboleta, lagartixa, peixes e outros. Depois vêm os cânticos de boi. A música costuma ser bem tocada e muito animada. No começo, Dona Raimundinha usa vestido de determinada cor, depois muda de roupa. A cada ano, na cura, ela usa roupas novas e diferentes. Depois de um intervalo, volta com o boi. Vem vestida de vaqueiro, com calça e colete de veludo colorido bordado sobre blusa, com chapéu do mesmo tecido do colete. Traz nos braços fitas coloridas amarradas e segura o maracá, que são objetos rituais usados na cura pelos pajés. Dona Raimundinha traz também uma vara na qual é pendurado um pequeno boizinho de veludo preto, bordado e enfeitado com saia colorida. No outro braço, traz uma toalha e a vara de ferrão. É seguida pela madrinha, que traz uma toalha branca e uma vela acesa na mão, e pelo padrinho, que segura outra vara de ferrão. Entrega então a vara de ferrão a um dos presentes e canta animada, afastando cadeiras, para que mais pessoas participassem da dança.

Dona Raimundinha, em transe com seu vaqueiro Laurentino, estimula que todos cantem. Às vezes reclama que estão cantando pouco e manda servirem mais bebidas. Em alguns momentos, canta em falsete, muito alto, que dificulta o acompanhamento do coro. Em dado momento, entoa o cântico de despedida e se retira do salão com o boizinho e os padrinhos para um intervalo, indo para um quarto trocar de roupa. Nós e alguns dos presentes costumamos sair neste momento, por volta das duas horas, mas 
sabemos que a cura continua até o amanhecer, com cânticos para linhas de caboclos, pretos velhos, Mãe d'Água, linha de cobra, linha de rã, de peixes e outras.

O boizinho representa um animal, mas deve ser batizado. A própria idéia de batizado do boi, que está muito presente na cultura e na religiosidade popular maranhense, reflete a presença do sincretismo e do hibridismo cultural.

\section{Observações sobre a Cura de Dona Raimundinha}

Como vimos, dona Maria Raimunda é uma líder religiosa que utiliza diversas práticas alternativas de cura para solucionar aflições dos que a consultam, recebendo clientes de diferentes camadas sociais. Ela é branca, porém originária de Codó, cidade do interior do Maranhão, onde a população negra é numerosa, e as religiões de origem africana têm grande expressão. Informa que herdou da mãe e da avó habilidades de cura e algumas entidades que cultua.

Para Dona Raimundinha a cura é uma das muitas atividades religiosas que ela realiza. Para fazer tratamentos, recebe mensagens das entidades, joga búzios, tarô, I Ching. Diz que seu poder é um dom que utiliza a serviço dos que a procuram. Como vimos, ela tem uma trajetória de vida com atuação em diversas profissões, em várias práticas alternativas de cura e nas religiões afro-brasileiras.

Sua festa de cura se inicia com uma ladainha católica, como costuma acontecer nas festas religiosas populares locais. Depois canta para mestres, nobres, caboclos e encantados, chamando todas as linhas de sua cura. Canta para santos católicos, para os mestres e para caboclos. Canta para diversos animais, que vai recebendo em transes sucessivos, como borboleta, sereia, boto e outros. Canta para nobres, príncipes e princesas, como ocorre sempre nos rituais de cura. Depois recebe e canta para Dom Sebastião, encantado no boi Turino Maitá, e para seu vaqueiro Lealdino, que faz o batizado do boizinho e que são os personagens principais do seu ritual de cura. Os cânticos para o povo de Dom Sebastião contam que ele vive nas dunas e morros de areia da praia dos Lençóis. No transe mediúnico, nos rituais de cura, o médium ou curador recebe grande número de entidades que se sucedem durante a noite, cada entidade permanecendo no transe enquanto se oferecem a ela alguns cânticos.

Os cânticos da cura, alguns incluídos em anexo, apresentam músicas e letras bonitas. Em geral cada série identifica determinadas entidades. Os textos não são fáceis de entender, pela pronúncia e pelo uso de linguagem figurada. Alguns são poéticos expressando uma filosofia de vida, como o que diz: "o tempo foi o meu mestre que me ensinou a curar", ou "pedi conselho ao vento". Alguns se relacionam com santos e 
elementos do catolicismo, outros se referem a termos e lugares conhecidos ou míticos como Maitá, Cabo das Tormentas, Boqueirão, Mar Ancião. Empregam palavras arcaicas ou pouco conhecidas, como bragado, sinônimo de malhado das manchas no couro, boi Turino, no sentido de touro, guarnicê, termo utilizado no bumba-meu-boi do Maranhão, com o sentido de reunir os brincantes. Aparecem os mestres da cura e personagens nobres como Duque do Pombal, Príncipe Navalheiro, Princesa Flora, Princesa Iná e outros, considerados parentes ou membros da corte de Dom Sebastião que apresentam algumas de suas características. Os cânticos refletem conhecimentos de uma filosofia popular que preserva imagens do passado, atualizadas no presente. Tais cânticos necessitam ser bem documentados para serem compreendidos.

Na simbologia e nos cânticos, encontramos a confluência de elementos da natureza local como animais e lugares, junto com personagens históricos ou criados que povoam o imaginário popular. O boizinho de Dom Sebastião é encontrado em muitas manifestações culturais maranhenses e pode ser estudado sob diferentes pontos de vista. Podemos analisá-lo sob a perspectiva da circularidade de culturas, do hibridismo, do sincretismo, do transculturalismo ou de empréstimos culturais, no contexto do sebastianismo nos cultos de possessão, da antropologia da performance e de acordo outras visões, que destacam o interesse deste ritual afro religioso, que ilustra a complexidade dos fenômenos da cultura popular.

\section{Conclusões}

Procuramos elaborar a etnografia de um ritual, interpretando o mito de origem relacionado com a produção simbólica e a identidade cultural de personagem da cultura popular. Verificamos que o imaginário religioso assume configurações particulares refletindo o diálogo entre culturas de diferentes origens e nacionalidades.

Mito e ritual são elementos inter-relacionados e possuem uma antiga tradição de abordagem desde os primórdios da Antropologia, que continuam sendo analisados e rediscutidos. De acordo com Malinowski, os estudos da mitologia e da magia se apresentam inter-relacionados. Magia seria como um "elo entre a mitologia e a realidade" (1976: 232).

Para Malinowski (1988), o mito constitui uma realidade viva que se relaciona com a paisagem, tem raízes na tradição e é atualizado nos ritos. Consideramos com Malinowski, que mito, ritual e magia estão inter-relacionados e se originam nas tradições locais, referindo-se ao espaço físico e ao tempo. Vemos que muitos nomes de acidentes locais são citados nos cânticos. Não pretendemos, entretanto, apresentar o 
mito e o ritual numa perspectiva holística de um todo integrado e acabado como faz Malinowski.

Tivemos a intenção, como sugere Geertz (1978), de elaborar uma descrição densa, como um texto preliminar, aberto a interpretações, procurando entender no mito e no ritual a estrutura de significados envolvidos e considerando a cultura como um fato não estático, mas dinâmico, que se modifica constantemente. Na perspectiva de Geertz, esse estudo não deve ser fechado, não está acabado.

Segundo Eliade (1986, p. 25), "toda história mítica que relata a origem de alguma coisa pressupõe e prolonga a cosmogonia.” Para Eliade, o mito tem função ritual nas curas e a maioria dos rituais terapêuticos evoca e reitera a criação do mundo como, se o xamã suplicasse que o mundo fosse novamente criado. Conforme Eliade (1986, p. 67), a idéia de regeneração e de recriação do mundo encontra-se em muitos mitos milenaristas presente em povos primitivos, que ele compara com a destruição das linguagens artísticas nas sociedades modernas, sobretudo na pintura e outras artes plásticas.

Como sabemos, o sincretismo ocorre em todas as culturas e em todas as religiões, mas em algumas delas parece ser mais evidente. O conceito que é antigo foi debatido pela Antropologia, sobretudo nas décadas de 1940 e 50, e depois foi praticamente relegado dos debates por certo esgotamento e por muitas críticas que foram feitas às teorias funcionalistas e de aculturação ao qual se encontrava mais vinculado. Como afirmam McGUIRE e MADURO (2005: 412-413), o termo em si é neutro, mas costuma receber conotações pejorativas devido a "julgamentos teológicos considerando que a mistura seria o resultado da miscigenação de uma religião doadora, pura e autêntica”.

Para Stewart e Shaw (2005), com o surgimento do conceito de invenção de tradições e de crítica da idéia de pureza ou autenticidade cultural e, com o advento da antropologia pós-moderna, o sincretismo passou a ser considerado um processo básico não só da religião e do ritual, mas da cultura como um todo. Para Stewart e Shaw, na pósmodernidade, a cultura passou a ser vista como uma invenção híbrida e sincretizada. Os autores se indagam: "Como usar o termo sincretismo hoje? A simples identificação de um ritual ou de uma tradição como sincrética não diz nada, pois todas as religiões têm origens compostas e são continuamente reconstruídas através de processos de síntese e substituição” (STEWART; SHAW, 2005, p. 07)

Hibridismo cultural é outro conceito antigo que tem sido desenvolvido e utilizado por alguns teóricos da pós-modernidade. Segundo Peter Burke (2003, p. 31): “devemos ver as formas híbridas como o resultado de encontros múltiplos e não como o resultado de um único encontro, quer encontros sucessivos adicionem novos elementos à mistura, 
quer reforcem os antigos elementos." Para o autor, o hibridismo se relaciona com a idéia de circularidade cultural e com termos ou idéias como empréstimo cultural, crioulização, imitação, mistura, tradução cultural e outros.

Constatamos que os conceitos de sincretismo, juntamente com o de hibridismo cultural, embora negados por alguns, são importantes para a compreensão de muitos aspectos das culturas e das religiões. Procuramos mostrar aqui a presença do sincretismo e do hibridismo através do mito e de rituais relacionados com a crença do sebastianismo na cultura afro-maranhense.

Os diversos elementos presentes nos mitos e no ritual de cura, o batizado do boi de Dom Sebastião, os cânticos entoados, a poesia neles implícita, a dança da pajoa, seus gestos, os papéis que desempenha, a participação dos músicos e dos presentes, a atuação das entidades sobrenaturais, a história das entidades e suas relações com o meio ambiente, a mitologia atualizada, tudo contribui para a representação do espetáculo que é encenado e vivido. Vemos que os rituais podem ser observados como espetáculo cuja descrição e interpretação ajudam a entender os significados das ações simbólicas neles contidas.

As religiões denominadas afro-brasileiras ou de matrizes africanas, possuem inúmeras variantes como reflexos de empréstimos, do sincretismo e do hibridismo cultural, que estão presente em todas as religiões e se refletem nos rituais e nos mitos de origem. $\mathrm{Na}$ pós modernidade, a religião e a cultura passam a ser vistas como híbridas e sincretizadas. A crítica ao conceito de pureza cultural e à noção de invenção de tradições contribui para uma nova aceitação do sincretismo e do hibridismo cultural, que enfrentaram resistências e hoje são novamente considerados como processo de compreensão não só da religião e do ritual, mas da cultura como um todo.

A presença de Dom Sebastião na encantaria maranhense mostra a força de mitos de origens, como do sincretismo entre entidades africanas, caboclas, européias e do catolicismo popular e entre este e as religiões afro-brasileiras, bem como a influência do meio ambiente na elaboração de crenças que estão muito enraizadas na mentalidade popular. A figura mítica de Dom Sebastião, transformado num touro encantado que aparece na ilha dos Lençóis e é recebido em transe, reforça a junção entre a crença messiânica na volta esperada do Rei, o folguedo do bumba-meu-boi e os rituais de cura e de tambor de mina das religiões afro-maranhenses. 
Como foi dito na Apresentação pelo Presidente da Comissão Científica deste Congresso ${ }^{18}$, "a memória histórica tem que ser encarada como um fator de diversidade cultural”. É importante "definir e defender os interesses e valores comuns, preservando as diferenças e fazendo delas um fator de encontro e preservação do patrimônio cultural". A coordenadora do evento ensina que "os mitos de origem estão intimamente conectados com a produção simbólica”. Verificamos, no ritual e no mito da cura de Dom Sebastião encantado na Ilha dos Lençóis, a presença desta memória e desta produção simbólica, como reflexo da diversidade e como fator de encontro de tradições que bem ilustra a riqueza das tradições culturais luso-afro-brasileiras.

\section{Referências bibliográficas}

ANDRADE, Joel Carlos Souza de. Os Filhos da Lua: Poéticas Sebastianistas na Ilha dos Lençóis - MA. Diss. de Mestrado. UFC/PPGHS: Fortaleza 2002.

ASSUNÇÃO, Luís Carvalho de. O Reino dos Encantados, Caminhos. Tradição e religiosidade no sertão nordestino. Tese de Doutorado. PUC/SP - PPGCS, São Paulo: 1999.

BAPTISTA, Maria Manuel. Mitos de Origens: Discursos Modernos e Pós-Modernos. Apresentação ao Congresso Europa das Nacionalidades. Lisboa, 2010. http//:europenations.web.ua.pt (acesso em 01.02.2011.

BOURDIEU, Pierre. O Poder Simbólico. Lisboa: DIFEL, 1989.

BRAGA, Pedro dos Santos. O Touro Encantado da Ilha dos Lençóis. O sebastianismo no Maranhão. Petrópolis: Vozes, 2001 (Ed. Original, São Luís: IPES, 1983).

BURKE, Peter. Hibridismo Cultural. São Leopoldo: Ed. Unisinos. 2003.

DANTAS, Beatriz Góis. Vovó nagô e papai branco. Usos e abusos da África no Brasil. Rio de Janeiro: Graal, 1988.

ELIADE, Mircea. Mito e Realidade São Paulo: Perspectiva, 1986.

FERRETTI, Mundicarmo M. Rocha. "Rei da Turquia, o Ferrabrás de Alexandria? A importância de um Livro na Mitologia do Tambor de Mina”. In: MOURA, C. E. M. de. (Org.), Meu Sinal está no Teu Corpo. Escritos sobre a religião dos orixás. (São Paulo: Edicom/Edusp, 1989), p 202-218.

2000 (a).

Desceu na Guma. O caboclo no Tambor de Mina. São Luís: EDUFMA,

Maranhão Encantado. Encantaria maranhense e outras histórias. São

Luís: UEMA, 2000 (b).

\footnotetext{
${ }^{18}$ Congresso Europa das Nacionalidades. Lisboa, 2010. http//:europe-nations.web.ua.pt (acesso em 01.02.2011).
} 
Siciliano, 2001.

Encantaria de "Barba Soeira" Codó, capital da magia negra? São Paulo: Pajelança do Maranhão no Século XIX, o processo de Amélia Rosa. São Luís: CMF/FAPEMA, 2004.

FERRETTI, Sergio F. Repensando o Sincretismo. São Paulo: EDUSP/FAPEMA, 1995. . Querebentã de Zomadonu. Etnografia da Casa das Minas. São Paulo: Pallas, 2009. (Original 1983).

O mito e ritos de Dom Sebastião no Tambor de Mina e no Bumba-meu-boi do Maranhão. In: Anais do $10^{\circ}$ Congresso Brasileiro de Folclore. São Luís: CNF/CMF, 2004, p 211-223.

Sincretismo, Religião e Culturas Populares. In: Ciências Humanas em Revista. São Luís: UFMA/CCH. Vol. 2. N. 1, 2004-b, p101-114.

. O boizinho de Dom Sebastião, apresentado no Fórum de Pesquisa Ritos da Cultura Popular, na 24${ }^{\mathrm{a}}$ Reunião da Associação Brasileira de Antropologia, realizada em Recife, em junho de 2004-c

Banquete dos cachorros para São Lázaro. São Luís: In: Boletim da Comissão Maranhense de Folclore, n. 19, jun. 2001, p 04-05.

GEERTZ, Clifford. A Interpretação das Culturas. Rio de Janeiro: Zahar, 1978

HERMANN, Jacqueline. No reino do Desejado. A construção do sebastianismo em Portugal séculos XVI e XVII. São Paulo: Companhia das Letras, 1998.

. O rei Sebastião no Maranhão: notas sobre o sebastianismo afro-caboclo da Ilha dos Lençóis. In: Antônio Herculano Lopes (Org.) Religião e Performance ou as performances na religião brasileira. Rio de Janeiro: Edições Casa de Rui Barbosa. 2008. v. 1.p 39-52.

HOBSBAWN, Eric e RANGER, Terence. A Invenção das tradições. São Paulo: Paz e Terra, 1997.

KADARÉ, Ismail. A ponte dos três arcos. Rio de Janeiro: Objetivo, 1999.

LIMA NETO, Bento Moreira. Histórias do Porto do Itaqui. São Luís: Idéia Criativa, 2005 .

LUCA, Taissa Tavernard. “Tem Branco na Guma”. A nobreza européia monto corte na Encantaria Mineira. Tese de Doutorado em Antropologia. Belém. UFPA/PPGCS, 2010.

MALINOWSKI, Bronislaw. Magia, Ciência e Religião. Lisboa, Ed. 70, 1988. . Argonautas do Pacífico Ocidental. São Paulo: Ed. Abril, 1976.

MAUÉS, Raimundo Heraldo. A Ilha Encantada. Diss. de Mestrado. PPGA/UNB. Pesquisa Antropológica No 22. Brasília: 1977. 
MAUÉS, Raimundo H e VILACORTA, Gisela M. Pajelanças e Religiões Africanas na Amazônia. Belém: Ed. Universitária, 2008.

McGUIRE, Meredith B e MADURDO, Otto. Au-dela du syncretism: Le bricolage en debat. Introduction. In: Social Compass. Revue Internationale de Sociologie de la Religion. Vol 52. No 4, Dec 2005, p 411-415.

MORAES, Jomar. O touro encantado e outras lendas maranhenses. São Luís: SIOGE, 1980.

PACHECO, Gustavo de Brito Freire. Brinquedo de Cura. Um estudo sobre a Pajelança Maranhense. Rio de Janeiro: UFRJ/PPGAS/Museu Nacional. Tese de Doutorado, 2004 .

PEREIRA, Madian de Jesus Frazão - O imaginário fantástico da Ilha dos Lençóis: estudo sobre a construção da identidade albina numa ilha maranhense. Diss. de Mestrado em Antropologia, UFPA/CFCH/DA, Belém: 2000.

PRANDI, José Reginaldo e SOUZA, PATRÍCIA R.. Encantaria de Mina em São Paulo. IN: PRANDI, Reginaldo (Org.) Encantaria Brasileira. Livro dos Mestres, Caboclos e Encantados. Rio de Janeiro: Pallas, 2001, p. 216-280.

STEWART, Charles \& SHAW, Rosalind. Syncretism / Anti-Syncretism. The Politics of Religious Synthesis. London and New York: Routlege, 2005.

VALENTE, Waldemar. Misticismo e Região (Aspectos do Sebastianismo Nordestino). Recife; IJNPS/MEC, 1963.

Van DER VEER, Peter. Syncretism, multiculturalism and the discourse of tolerance. In: STEWART, C. and SHAW, R. Syncretism / Anti-Syncretism. The Politics of Religious Synthesis. . London and New York: Routledge. 2005, p.196-211.

VERGOLINO-HENRY, Anaíza. Um encontro na encantaria: notas sobre a inauguração do "Monumental Místico Rei Sabá. In: Anais do $10^{\circ}$ Congresso Brasileiro de Folclore. São Luís: CNF/CMF, 2004, p 158-164.

Vídeo:

MACHADO, Roberto. A lenda do Rei Sebastião, São Paulo, Tempo Filmes, 1979, Documentário $14^{\prime}$ VHS-NTSC

Sergio F. Ferretti é doutor em Antropologia, professor do Departamento de Sociologia e Antropologia da UFMA, vinculado aos Programas de Pós-Graduação em Ciências Sociais e em Políticas Públicas. Publicou diversos artigos e entre outros os livros: Repensando o Sincretismo (Edusp, 1995); Querebentã de Zomadonu (Pallas, 2009); Tambor de Crioula: ritual e espetáculo (CMF, 2002).

ferrettisf@gmail.com 


\section{ANEXO: letras das toadas anotadas na Cura}

o1) Meu Senhor que está naquela cruz, Eu vou abrir a minha mesa em nome de Jesus.

o2) Eu vou abrir a minha mesa - Meu Pombo Roxo "avuador".

03) Meu Santo Antônio, meu santo protetor, Eu já abri a minha mesa, Nosso Senhor que mandou.

04) O meu Deus como eu sou sozinho, cumprindo com a minha sina, tocando o meu maracá.

o5) Marajá, Marajá tem dó. Põe a rama no caminho, não deixa o contrário entrar. (Derrama cachaça nos quatro cantos do salão).

o6) Eu chamo pelo meu mestre. Vou chamar pelo meu Guia. Vou buscar pelo meu mestre, no rolo da Maresia.

o7) Mestre Cirilo já chegou. Esse mestre e contra mestre. Ele é bom curador.

o8) Eu tenho guia firme, foi meu mestre quem mandou, um é o Rei dos Mestres, outro é o Rei Nagô.

o9) Eu tava brincando na areia, quando mamãe me chamou. Me chamou papai, me chamou mamãe, pra eu ser um mestre curador.

10) O tempo foi o meu mestre, que me ensinou a curar, corre depressa menino, corre depressa e vem cá, vai buscar minha conta nesta guia do meu maracá. (Paródia de Antônio Luís Corre Beirada, filho bastardo de Dom Luiz Rei de França)

11) Nos astros eu sou um mestre, na terra eu sou doutor, no mar eu sou um peixe na terra bom curador. (Toada de Antônio Luís)

12) Pedi conselho ao vento, o tempo me respondeu: menino presta atenção, que o seu mestre sou eu. (Toada de Antônio Luís).

13) Passei na luz da candeia e no balanço do Mar, Dona Ana veio da Corte, Dona Ana veio da Corte. Ela veio da banda de lá.

14) Eu sou uma borboleta, eu quero voar, meu pai é caçador da mata real. (Princesa encantada numa borboleta).

15) Na passagem do riacho, Maria me deu a mão. Mas eu sou Mariazinha, no meio do Boqueirão. (Princesa Maria da Conceição) 
16) Eu sou aquela Princesa, eu moro no Mar Ancião, meu pai é o Rei Sebastião, minha madrinha a Virgem da Conceição. (Princesa Maria da Conceição)

17) Eu quero .... eu quero ir lá, sou a moça da Pedra Fina, moro nas ondas do mar.

18) O mana minha, ó linda sereia, Urubarana senhora guerreira. (Princesa Urubarana)

19) Princesa Flora tem papai e tem mamãe, Princesa Flora já foi filha hoje é mãe. É no luar, é no luar, Princesa Flora só passei no luar.

20) Eu sou menina do Cai Cai, do Cai Cai, do Caidô, eu sou menina do Cai Cai Cai Cai Caidô.

21) Chegou moço Batalha, ele é batalhador, na província onde mora ele é governador. (Toada de Ogum)

22) Olha o Duque, olha o Duque, olha o Duque do Pombal, olha o Duque deixa o Duque se sentar.

23) No meu condado quem governa sou eu. Eu mando e ordeno, com o poder que Deus me deu.

24) Sou João, sou João Soeiro, sou Guerreiro. Entre serras e batalhas eu sou João. Eu sou o Príncipe Navalheiro.

25) No Cabo das Tormentas eu me encantei, quando meu navio "afundeou", mas eu também sou nobre, sou filho do imperador.

26) Oh! que caminho tão longo. Oh! que estrada tão tirana. Eu me chamo Constantino, sou baiano Chapéu de Couro. (Toada de Baiano Grande)

27) E só parece que a Bahia se perdeu. E só parece que o vento levou. Eu venho da Bahia. Eu sou baiano e moro na mina de ouro.

28) Boi Turino, boi Turino, boi Turino Maitá. Eu cavo na areia, lá nas ondas do mar.

29) Você diz que é boi na roda, boi bragado vem rodar.

30) Meu bom vaqueiro vai buscar meu boi laranja. Esse boi é meu, esse boi é meu.

31) Meu boi está no terreiro. Eu quero ver o meu boi brincar.

32) $\hat{E}$, ê, ê boi. Morena sacode os cabelos, vem ver seu vaqueiro partir. Morena eu moro no morro de areia, eu vou meu gado reunir. 
33) Tremeu, tremeu, eu vi a terra tremer. Vou "guarnicê", o meu boi bonito fica aqui até o amanhecer.

34) Vou batizar o meu boi Estrela Maior.

35) O meu boi bonito já foi batizado, oi vaqueiro nobre vai buscar a boiada.

36) Todo mundo quer saber o meu nome, para fazer confusão, mas eu venho das quatro partes do mar, guiado por São João.

37) Meu glorioso São João. Ele é meu padrinho é meu santo protetor. Naquela fogueira que o senhor me batizou, São Pedro disse Lealdino é vaquejador.

38) Sou o vaqueiro Lealdino, eu moro num morro de areia no meio do mar, digo adeus a meu povo, pois eu vou me "arretirar".

39) Tenho meu cordão de ouro, meu penacho de pavão. O que moço tão bonito é o Rei Sebastião (Ouvido em outro ritual) 